\title{
Biogeochemical consequences of ocean acidification and feedbacks to the earth system
}

\author{
Marion Gehlen, Nicolas Gruber, Reidun Gangstø, Laurent Bopp, \\ and Andreas Oschlies
}

\subsection{Introduction}

By the year 2008, the ocean had taken up approximately $140 \mathrm{Gt}$ carbon corresponding to about a third of the total anthropogenic $\mathrm{CO}_{2}$ emitted to the atmosphere since the onset of industrialization (Khatiwala et al. 2009). As the weak acid $\mathrm{CO}_{2}$ invades the ocean, it triggers changes in ocean carbonate chemistry and ocean $\mathrm{pH}$ (see Chapter 1). The $\mathrm{pH}$ of modern ocean surface waters is already 0.1 units lower than in pre-industrial times and a decrease by 0.4 units is projected by the year 2100 in response to a businessas-usual emission pathway (Caldeira and Wickett 2003). These changes in ocean carbonate chemistry are likely to affect major ocean biogeochemical cycles, either through direct $\mathrm{pH}$ effects or indirect impacts on the structure and functioning of marine ecosystems. This chapter addresses the potential biogeochemical consequences of ocean acidification and associated feedbacks to the earth system, with focus on the alteration of element fluxes at the scale of the global ocean. The view taken here is on how the different effects interact and ultimately alter the atmospheric concentration of radiatively active substances, i.e. primarily greenhouse gases such as $\mathrm{CO}_{2}$ and nitrous oxide $\left(\mathrm{N}_{2} \mathrm{O}\right)$.

Changes in carbonate chemistry have the potential for interacting with ocean biogeochemical cycles and creating feedbacks to climate in a myriad of ways (Box 12.1). In order to provide some structure to the discussion, direct and indirect feedbacks of ocean acidification on the earth system are distinguished (Table 12.1 and Fig. 12.1). Direct feedbacks are those which directly affect radiative forcing in the atmosphere by altering the air-sea flux of radiatively active substances. Indirect feedbacks are those that first alter a biogeochemical process in the ocean, and through this change then affect the air-sea flux and ultimately the radiative forcing in the atmosphere. For example, when ocean acidification alters the production and export of organic matter by the biological pump, then this is an indirect feedback. This is because a change in the biological pump alters radiative forcing in the atmosphere indirectly by first changing the nearsurface concentrations of dissolved inorganic carbon and total alkalinity. These changes will in turn affect the air-sea flux of $\mathrm{CO}_{2}$. The magnitude of the indirect feedbacks associated with biological pumps depends on at least three elements: (1) the magnitude of the impact that ocean acidification has on a particular aspect of the ocean's biological pumps, (2) how these changes in the biological pumps affect the ocean's carbonate chemistry, and (3) how these changes in carbonate chemistry affect the air-sea $\mathrm{CO}_{2}$ flux. For example, the response of the air-sea $\mathrm{CO}_{2}$ flux to a given change in the export of organic carbon from near-surface waters may vary by up to a factor of 10 , depending on where and how this change occurs (e.g. Jin et al. 2008; Oschlies 2009).

By far the most important direct feedback is that associated with ocean acidification changing the buffer (Revelle) factor of the ocean. As discussed in detail in Chapter 3, the ocean's capacity to hold additional $\mathrm{CO}_{2}$ from the atmosphere is inversely 


\section{Box 12.1 The concept of feedback and ocean acidification}

A feedback is an interaction mechanism in which the result of an initial process drives changes in a second process that in turn influences the initial one. A positive feedback intensifies the original process, while a negative feedback reduces it. In the climate system, one of the main positive feedbacks is the tendency of warming to increase the quantity of water vapour in the atmosphere, and hence the greenhouse effect and earth's warming itself. Ocean acidification, a direct consequence of increasing levels of atmospheric $\mathrm{CO}_{2}$, interacts with biogeochemical processes, alters air-sea exchange of $\mathrm{CO}_{2}$, and hence atmospheric $\mathrm{CO}_{2}$. If ocean acidification leads to an increase (decrease) in atmospheric $\mathrm{CO}_{2}$ then this represents a positive (negative) feedback. In this chapter, the notion of feedback is extended to include the effect of ocean acidification on climate not only through changes in atmospheric $\mathrm{CO}_{2}$ ( $\mathrm{CO}_{2}$-acidification feedback), but also through changes in other atmospheric constituents (e.g. nitrous oxide and dimethyl sulphide) which do not represent, strictly speaking, feedbacks on $\mathrm{CO}_{2}$. proportional to the Revelle buffer factor, i.e. the larger this factor, the lower the capacity of the ocean to take up additional $\mathrm{CO}_{2}$. Ocean acidification increases the Revelle buffer factor, causing a drastic decrease in the capacity of ocean water to take up $\mathrm{CO}_{2}$ from the atmosphere, leading to a decrease in the rate of uptake and a transient accumulation of $\mathrm{CO}_{2}$ in the atmosphere.

The majority of the indirect feedbacks are those affecting the ocean's biological pumps (both organic and carbonate). Two groups of indirect feedbacks can be identified: group 1, in which ocean acidification affects the biological pumps directly, and group 2, in which ocean acidification affects a particular ocean biogeochemical process, which in turn alters the biological pumps.

The stimulation of marine photosynthesis by increased levels of $\mathrm{CO}_{2}$ (Rost et al. 2008) is an example of an indirect group 1 feedback. However, the extent of $\mathrm{CO}_{2}$ fertilization depends on the physiological characteristics of individual phytoplankton groups. It is higher in organisms with an inefficient carbon acquisition pathway. A second indirect effect of the first group is the change in calcification (Fabry et al. 2008, but see also IglesiasRodriguez et al. 2008). An example of an indirect effect of the second group is the reported enhancement of dinitrogen $\left(\mathrm{N}_{2}\right)$ fixation by cyanobacteria at elevated $\mathrm{pCO}_{2}$ concentrations (Hutchins et al. 2009). This process represents a major source of reactive nitrogen $(\mathrm{N})$ to oligotrophic tropical and subtropical areas, and given the $\mathrm{N}$-limited nature of these areas, has the potential to substantially increase primary production.
Over recent years, an increasing number of studies have addressed the effects of ocean acidification on isolated processes based on first-order chemical principles (e.g. trace metal speciation) or controlled process studies (e.g. $\mathrm{N}_{2}$ fixation, calcification, photosynthesis). While these studies provided new and valuable insights into, for example, the vulnerability of specific processes in response to ocean acidification, they do not allow us to apprehend impacts at the scale of the marine biogeochemical cycle. Scaling up from the level of physiological processes to that of organisms and ecosystems is not straightforward and challenges global biogeochemical modelling efforts. It is further complicated by the fact that ocean acidification does not occur in isolation, but in synergy with ocean warming and related changes in the physical environment that might amplify or alleviate its impacts (e.g. Brewer and Peltzer 2009). All these changes taken together will alter the partitioning of climate-relevant gases between the ocean and the atmosphere.

This chapter presents a synthesis of our understanding of impacts of ocean acidification on marine biogeochemical cycles, including its interaction with climate change and feedbacks to the earth system. It starts with the discussion of the marine carbon cycle, an area for which experimental and modelling studies allow a first-order evaluation of impacts and feedbacks, moves to the nitrogen cycle and ends with atmospherically active trace gases. Impacts are discussed together with associated feedbacks and, when possible, taking into account climate change. 
PHOTOSYNTHESIS (Fertilization)

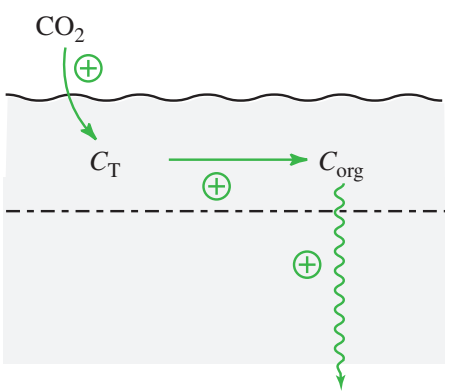

DMS PRODUCTION

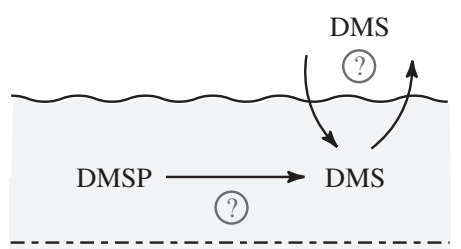

C:N STOICHIOMETRY

$\mathrm{CO}_{2}$

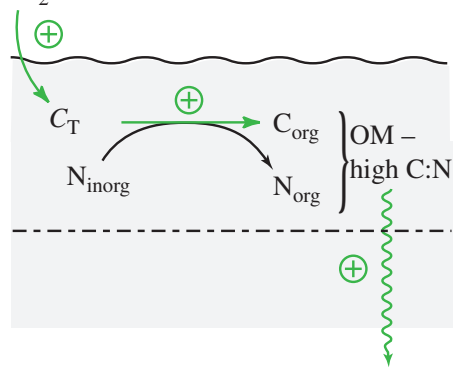

BALLAST EFFECT

$\mathrm{CO}_{2}$

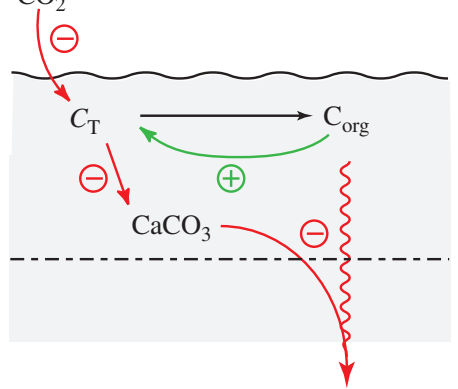

CALCIFICATION

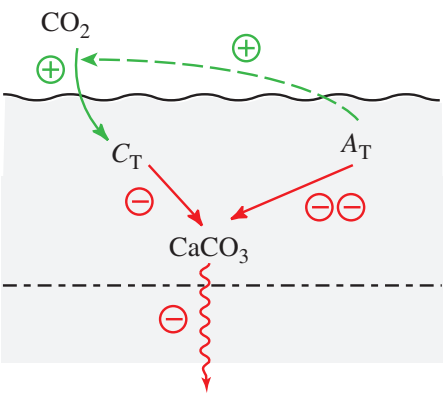

$\mathrm{CaCO}_{3}$ DISSOLUTION

$\mathrm{CO}_{2}$

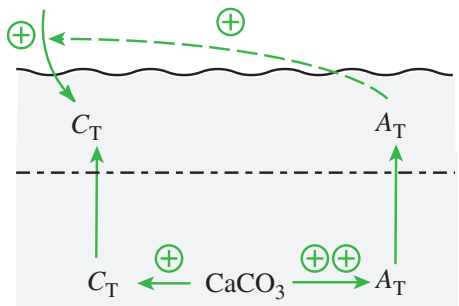

INDIRECT EFFECTS (Group 2)

$\mathrm{N}_{2}$ FIXATION

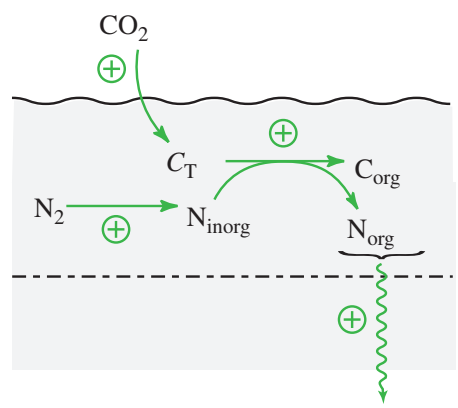

NITRIFICATION

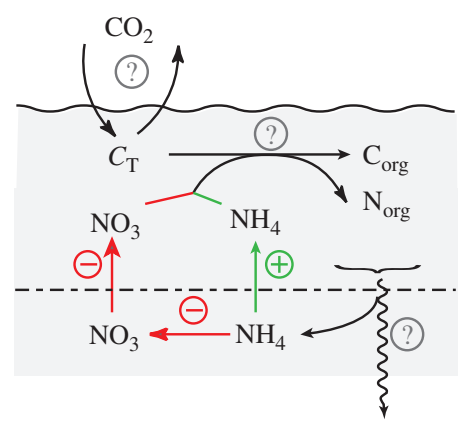

OXYGEN-DENITRIFICATION

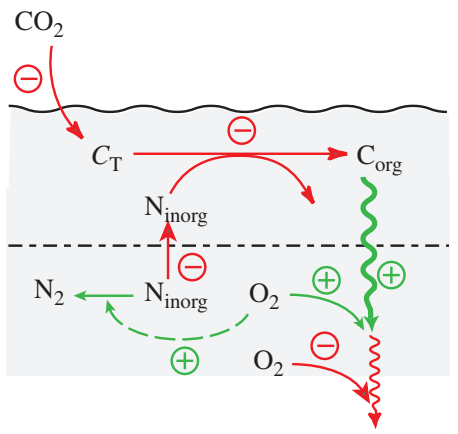

$\mathrm{N}_{2} \mathrm{O}$ PRODUCTION

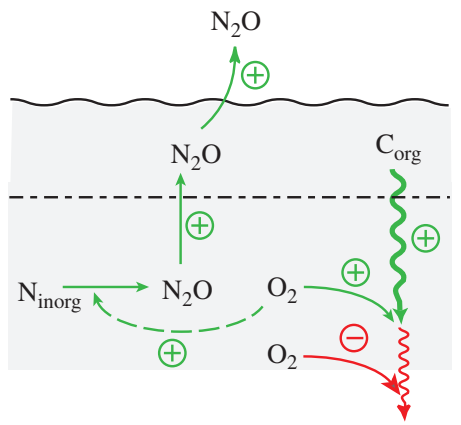

Figure 12.1 Summary of feedbacks between the ocean's biogeochemical cycles and radiative forcing induced by ocean acidification. Shown are the pathways that ultimately lead to a change in the atmospheric concentration of radiatively active components, namely $\mathrm{CO}_{2}, \mathrm{~N}_{2} \mathrm{O}$, and DMS. Refer to the text and Table 12.1 for a detailed discussion. Solid arrows indicate fluxes and/or transformations, while dashed arrows indicate that this quantity has an influence on the flux/transformation. The dot-dashed horizontal line depicts the boundary between the euphotic and the aphotic zones. 
Table 12.1 Summary of effects and feedbacks. A positive (negative) feedback tends to increase (decrease) atmospheric $\mathrm{CO}_{2}$ (see $\mathrm{Box}_{12.1)}$

\begin{tabular}{|c|c|c|c|c|}
\hline Process & Causality & $\begin{array}{l}\text { Sign of } \\
\text { feedback }\end{array}$ & Magnitude & $\begin{array}{l}\text { Level of } \\
\text { understanding }\end{array}$ \\
\hline \multicolumn{5}{|l|}{ Direct feedbacks } \\
\hline $\mathrm{CO}_{2}$ buffer factor & Decrease of ocean uptake capacity & Positive & Large & High \\
\hline \multicolumn{5}{|l|}{ Indirect group 1 feedbacks } \\
\hline Photosynthesis & $\begin{array}{l}\text { Enhancement of biological production and export by } \mathrm{CO}_{2} \\
\text { fertilization }\end{array}$ & Negative & Medium & Medium \\
\hline Export: stoichiometric ratio & $\begin{array}{l}\text { Increase of } \mathrm{C}: \mathrm{N} \text { ratio, thereby enhancing marine productivity } \\
\text { in terms of carbon }\end{array}$ & Negative & Small to medium & Low \\
\hline Calcification & $\begin{array}{l}\text { Decrease of marine calcification (BUT mixed experimental } \\
\text { evidence) }\end{array}$ & Negative & Small to medium & Low to medium \\
\hline $\mathrm{CaCO}_{3}$ dissolution & $\begin{array}{l}\text { Increase in dissolution of } \mathrm{CaCO}_{3} \text { in particles and sediments, } \\
\text { thereby increasing ocean alkalinity }\end{array}$ & Negative & $\begin{array}{l}\text { Small (short-term) } \\
\text { — large on long } \\
\text { timescales }\end{array}$ & Medium \\
\hline $\begin{array}{l}\text { Remineralization: ballast } \\
\text { effect }\end{array}$ & $\begin{array}{l}\text { Decrease of } \mathrm{CaCO}_{3} \text { production, leading to reduced org. } \\
\text { matter export }\end{array}$ & Positive & Small to medium & Low \\
\hline DMS production & Enhancement or reduction of DMS production & Unknown & Unknown & Low \\
\hline \multicolumn{5}{|l|}{ Indirect group 2 feedbacks } \\
\hline $\mathrm{N}_{2}$ fixation & $\begin{array}{l}\text { Enhancement of biological fixation of } \mathrm{N}_{2} \text {, increasing } \\
\mathrm{N} \text { inventory, enhancing biological production }\end{array}$ & Negative & Medium & Medium \\
\hline Oxygen denitrification & $\begin{array}{l}\text { Reduction in penetration depth of organic matter, shallow } \\
\text { remineralization creating higher } \mathrm{O}_{2} \text { demand in low- } \mathrm{O}_{2} \\
\text { regions, causing expansion of these regions, enhancing } \\
\text { denitrification, lowering } \mathrm{N} \text { inventory, lower biological } \\
\text { production }\end{array}$ & Positive & Medium & Low \\
\hline Nitrification & Reduction in nitrification & Unknown & Small & Low \\
\hline Nitrous oxide production & $\begin{array}{l}\text { Decrease in oxygen concentrations, enhancing } \\
\mathrm{N}_{2} \mathrm{O} \text { production }\end{array}$ & Positive & Medium & Low \\
\hline
\end{tabular}

\subsection{The marine carbon cycle}

The marine carbon cycle is an essential component of the earth system, participating in the long-term stabilization of atmospheric $\mathrm{CO}_{2}$ levels. The oceans are by far the largest reservoir for carbon, with the exception of sedimentary rocks (Falkowski et al. 2000; see Chapter 2). They interact with the atmosphere on a variety of timescales ranging from hours (daily cycle of biological production) over seasons (mixed-layer dynamics), to several centuries (large-scale ocean circulation), and up to several thousands of years (interaction with marine sediments through the mechanism of $\mathrm{CaCO}_{3}$ compensation). A crucial element of this interaction is the fact that the surface ocean is substantially depleted in dissolved inorganic carbon $\left(C_{T}\right)$ relative to the deep ocean, requiring processes that transfer carbon from the near-surface to depth in order to maintain this downward gradient against homogenization by mixing and transport (Volk and Hoffert 1985). Three pathways have been identified as gradient makers ('pumps'): the solubility pump, the carbonate pump, and the soft tissue pump. The latter two are often collectively referred to as the biological pump. Ocean acidification, by modifying the carbonate chemistry of the surface ocean and environmental conditions for marine biota, interacts with all three pumps ultimately altering the air-sea balance of $\mathrm{CO}_{2}$.

\subsubsection{The solubility pump}

The solubility pump refers to the physico-chemical process driving the uptake of $\mathrm{CO}_{2}$ and its downward mixing and transport along with the large-scale 
ocean circulation. The solubility of $\mathrm{CO}_{2}$ increases with decreasing temperature and is thus higher at high latitudes where deep-water formation takes place. The combined effects of solubility and deepwater formation result in a downward transport of $\mathrm{CO}_{2}$-enriched water masses and thus higher $\mathrm{C}_{\mathrm{T}}$ concentrations at depth (see Chapter 3).

The equilibrium reactions of the carbonate system are at the origin of the large uptake capacity of the ocean for $\mathrm{CO}_{2}$. However, as for any buffer system, its capacity is not infinite. As discussed in Chapter 3, the Revelle factor, a measurement of the buffer capacity, increases (decreasing buffer capacity) with increasing atmospheric $\mathrm{CO}_{2}$. As a result, the strength of the ocean sink for $\mathrm{CO}_{2}$ is going to decrease in the future, a direct positive feedback of ocean acidification to atmospheric $\mathrm{CO}_{2}$ levels and hence to the earth system. This positive feedback is very substantial, i.e. in a business-as-usual scenario it may be as large as 30\% in the next 100 years (Sarmiento et al. 1995). Hydration of gaseous $\mathrm{CO}_{2}$ and the equilibration between individual dissolved species of the carbonate system are dependent on temperature and salinity. Both will change in response to global climate change. Climate change aggravates the chemical effect of decreasing buffer capacity in two ways: (1) due to the inverse relationship between temperature and $\mathrm{CO}_{2}$ solubility (Chapter 3) and (2) due to the increase in stratification and the anticipated slowdown of the surface-to-deep exchange of carbon (Sarmiento et al. 1998).

\subsubsection{The carbonate pump}

The carbonate pump is driven by the precipitation of $\mathrm{CaCO}_{3}$ by marine organisms, the settling of carbonate particles across the water column, and their dissolution at depth in undersaturated waters and burial in sediments. Since the precipitation of $\mathrm{CaCO}_{3}$ reduces the total alkalinity of the seawater more than it decreases its $C_{\mathrm{T}^{\prime}}$ this process increases the concentration of dissolved $\mathrm{CO}_{2}$ and thus the partial pressure of $\mathrm{CO}_{2}\left(p \mathrm{CO}_{2}\right)$ of near-surface waters. This can also be understood by recognizing that the removal of the carbonate ion $\left(\mathrm{CO}_{3}^{2-}\right)$ by the precipitation of $\mathrm{CaCO}_{3}$ leads to a redistribution of the different species of the carbonate system in such a way that the dominant $C_{\mathrm{T}}$ species at the $\mathrm{pH}$ of surfaceocean waters, i.e. bicarbonate $\left(\mathrm{HCO}_{3}^{-}\right)$, will dissociate in order to replenish the lost $\mathrm{CO}_{3}^{2-}$ but thereby generating dissolved $\mathrm{CO}_{2}$ as well:

$$
\begin{gathered}
\mathrm{Ca}^{2+}+\mathrm{CO}_{3}^{2-} \rightarrow \mathrm{CaCO}_{3}(\mathrm{~s}) \\
2 \mathrm{HCO}_{3}^{-} \rightarrow \mathrm{CO}_{3}^{2-}+\mathrm{CO}_{2}+\mathrm{H}_{2} \mathrm{O}
\end{gathered}
$$

or written as a summary equation:

$$
\mathrm{Ca}^{2+}+2 \mathrm{HCO}_{3}^{-} \rightarrow \mathrm{CaCO}_{3}(\mathrm{~s})+\mathrm{CO}_{2}+\mathrm{H}_{2} \mathrm{O} .
$$

Thus the carbonate pump tends to force $\mathrm{CO}_{2}$ out of the ocean into the atmosphere, despite the fact that it leads to a depletion of $C_{\mathrm{T}}$ in the upper ocean.

The saturation state with respect to $\mathrm{CaCO}_{3}$ decreases with depth, largely owing to the soft-tissue pump that acidifies the deep ocean as a result of the release of metabolic $\mathrm{CO}_{2}$ during the remineralization of the organic matter transported downwards (Gruber and Sarmiento 2002). The saturation state has a direct impact on the formation and dissolution of carbonate structures. Throughout this discussion, the saturation state of seawater with respect to a $\mathrm{CaCO}_{3}$ mineral $(\Omega)$ defined by Zeebe and Gattuso (see Box 1.1 in Chapter 1) is used. The stoichiometric solubility product increases with depth as a result of increasing pressure and decreasing temperature.

\subsubsection{Calcium carbonate production}

In the modern ocean, $\mathrm{CaCO}_{3}$ formation is largely a biotic process. While inorganic precipitation and dissolution of $\mathrm{CaCO}_{3}$ are a direct function of the saturation state (Morse et al. 2007), the mechanisms of calcification and their sensitivity to changes in carbonate chemistry are less well understood (see Chapters 6 and 7). The diversity of responses of calcifiers to a decrease in saturation state of seawater challenges global ocean biogeochemical models. These models represent $\mathrm{CaCO}_{3}$ formation as a geochemical source/sink function of varying complexity with a limited number of studies including a dependency on carbonate chemistry. In its simplest expression, $\mathrm{CaCO}_{3}$ production is implemented as a constant fraction of organic carbon production modulated by a dependency on saturation state 
(Ridgwell et al. 2007). In Heinze (2004), pre-industrial $\mathrm{CaCO}_{3}$ export production was computed as a constant function of the organic carbon export that is not driven by silicifying organisms. A third approach assigns $\mathrm{CaCO}_{3}$ production to a specific phytoplankton functional type, the nanophytoplankton, which corresponds to the size class of coccolithophores (Gehlen et al. 2007). In this model $\mathrm{CaCO}_{3}$ export production is a function of irradiance, nutrient availability, nanophytoplankton biomass, grazing by micro- and mesozooplankton, and saturation state with respect to calcite. These models consider the formation and dissolution of the less soluble $\mathrm{CaCO}_{3}$ polymorph calcite. The different parameterizations of calcite production as a function of carbonate chemistry rely on a limited number of studies. Gangstø et al. (2008) extended the conceptual approach originally derived for calcite production by nanophytoplankton by Gehlen et al. (2007) to the production of aragonite by mesozooplankton. At the time of this model sensitivity study, no data were available to derive a parameterization of aragonite production by pteropods based on observations. Since the study by Gangstø et al. (2008) was published, experimental data on the calcification response of pteropods as a function of carbonate chemistry have become available. More recently, the models were extended further to include a parameterization specific for pteropods (Gangstø et al. 2011).

In all models, $\mathrm{CaCO}_{3}$ production is linked to the production of particulate organic carbon (POC) through the rain ratio. The latter is defined as the ratio of $\mathrm{CaCO}_{3}$ to POC flux and corresponds to the relevant quantity in terms of biogeochemical impacts and feedbacks to atmospheric $\mathrm{CO}_{2}$ (e.g. Archer and Maier-Reimer 1994). On average, the rain ratio is about 0.09 (Jin et al. 2008). The POC production did not respond to changes in carbonate chemistry in any of these studies, despite some experimental evidence for an increase in POC production in response to increased levels of $\mathrm{CO}_{2}$ (e.g. Zondervan et al. 2001).

\subsubsection{Calcium carbonate dissolution}

Dissolution of $\mathrm{CaCO}_{3}$ is an abiotic process driven by thermodynamics, i.e. the degree of undersaturation. This implies that the dissolution of $\mathrm{CaCO}_{3}$ is bound to increase in response to decreasing saturation state. The resulting increase of total alkalinity favours $\mathrm{CO}_{2}$ uptake, a negative indirect group 1 feedback.

The dissolution of $\mathrm{CaCO}_{3}$ is usually described by a higher-order reaction rate law with respect to undersaturation:

$$
R=k \times(1-\Omega)^{n}
$$

where $n$ is the reaction order and $k$ is the dissolution rate parameter $\left(\right.$ time $\left.^{-1}\right)$.

Published estimates of $n$ range from 1 to 4.5 (Keir 1980; Hales and Emerson 1997; Gehlen et al. 2005) based on laboratory studies and the evaluation of sediment porewater data. The higher-order rate law implies that dissolution rates are low at modest levels of undersaturation and increase following a power law as a function of increasing undersaturation. As a result, when normalized to a given value of $\Omega$, the higher-order rate law translates to an initial lower sensitivity to decreases in saturation state compared with the linear rate expression.

The dissolution of sinking $\mathrm{CaCO}_{3}$ particles is implemented into some global biogeochemical models as a first-order rate law, i.e. $n=1$ (e.g. Heinze 2004; Gehlen et al. 2007; Gangstø et al. 2008). In contrast, Ridgwell et al. (2007) do not explicitly solve for $\mathrm{CaCO}_{3}$ dissolution, but rather apply a constant depth-penetration profile to the $\mathrm{CaCO}_{3}$ export flux, an approach used by most models that do not include a sensitivity of their biogeochemical processes to ocean acidification.

\subsubsection{Interaction with carbonate sediments}

The vast reservoir of mineral carbonates in the sediments provides the ultimate buffer against ocean acidification (see Chapter 2). If those carbonates were to dissolve readily in response to a decrease in the saturation state of the overlying waters, ocean acidification would not be a problem. The sediments would resupply the carbonate ions that are titrated away by the invading anthropogenic $\mathrm{CO}_{2}$, thus keeping $\mathrm{pH}$ changes to a minimum. Unfortunately, the ocean's sediment pool will be reacting very slowly to the invasion of anthropogenic $\mathrm{CO}_{2}$ and the associated ocean acidification. First, because it takes time for anthropogenic $\mathrm{CO}_{2}$ 
to invade the ocean causing the $\mathrm{CO}_{3}^{2-}$ concentration to decrease and exposing increasing areas of marine carbonate sediments to undersaturated waters. Second, the dissolution rates are very small. As a result, it will take thousands of years for this compensation to occur (e.g. Archer 2005). Sundquist (1990) estimated that about $60 \%$ of the total buffering of an atmospheric $\mathrm{CO}_{2}$ perturbation by ocean processes can be attributed to circulation with characteristic timescales of several centuries. The interaction with carbonate sediments will neutralize the remaining $40 \%$. The majority of ocean biogeochemical models that are concerned about projecting the evolution of ocean acidification over the next centuries do not include the sediment pool. In strong contrast, if one wants to consider the long-term consequences of ocean acidification or model past geological events, it is absolutely critical to include this compartment as well (e.g. Ridgwell and Hargreaves 2007).

\subsubsection{Future projections: impacts and feedbacks}

Given that calcification increases surface-ocean $p \mathrm{CO}_{2}$ (Eq. 12.1), a decrease in calcification in response to a decrease in the $\mathrm{CaCO}_{3}$ saturation state would translate into an additional uptake of $\mathrm{CO}_{2}$. The opposite would be the case if calcification were to increase. Thus, a decrease in calcification tends to act as a negative indirect group 1 feedback.

To illustrate the evolution of carbonate chemistry and its impact on the marine carbonate cycle in more detail, we use output from an ocean biogeochemistry model that was run following the standard scenario of the Coupled Model Intercomparison Project (CMIP; http://www-pcmdi.llnl. gov/projects/cmip/index.php). In this scenario, atmospheric $p \mathrm{CO}_{2}$ increases at a rate of $1 \% \mathrm{yr}^{-1}$ from 286 (referred to as $\left.1 \times \mathrm{CO}_{2}\right)$ to $1144\left(4 \times \mathrm{CO}_{2}\right) \mathrm{ppmv}$ over a 140 year time period (Fig. 12.2A). Three sensitivity experiments were undertaken during this study (Gehlen et al. 2007). In experiment CAL01, both $\mathrm{CaCO}_{3}$ production and dissolution responded to changes in carbonate chemistry, while in experiment CAL02, $\mathrm{CaCO}_{3}$ production was kept constant at pre-industrial levels, but dissolution responded to ocean acidification. Finally, in experiment CAL03 production and dissolution of $\mathrm{CaCO}_{3}$ were kept at pre-industrial levels.
The mean global saturation state of surface-ocean waters with respect to calcite $\left(\Omega_{c}\right)$ decreases from $\Omega_{c}>5$ at year 0 to $\Omega_{c}=2$ at the end of the acidification scenario (Fig. 12.2B). The model projects a decrease in $\mathrm{CaCO}_{3}$ production of $27 \%$ (Fig. 12.2C). In experiment $\mathrm{CAL01}, \mathrm{CaCO}_{3}$ dissolution decreases by $16 \%$, reflecting a reduction in $\mathrm{CaCO}_{3}$ production and thus the availability of particles for dissolution (Fig. 12.2.D). When normalized to production, carbonate dissolution increases from $61 \%$ at $1 \times p \mathrm{CO}_{2}$ to $72 \%$ at $4 \times p \mathrm{CO}_{2}$. In experiment CAL02, water-column dissolution increases by $19 \%$ relative to the pre-industrial state. The reduction in $\mathrm{CaCO}_{3}$ production (CAL01) drives an additional uptake of 5.9 Gt C relative to CAL03 over the course of the simulation (Fig. 12.2.E). This corresponds to a very modest decrease in atmospheric $\mathrm{CO}_{2}$ of about $2.8 \mathrm{ppmv}$, i.e. equivalent to 2 years of current levels of growth of atmospheric $\mathrm{CO}_{2}$. The increase in dissolution flux alone (CAL02) gives rise to an excess uptake of 1.2 Gt C. In this particular model study, the substantial decrease in $\mathrm{CaCO}_{3}$ production combined with the increase in relative dissolution translates to an overall modest negative feedback to atmospheric $\mathrm{CO}_{2}$.

How robust are these future projections of $\mathrm{CaCO}_{3}$ production and dissolution across models? At the same atmospheric $\mathrm{CO}_{2}$ level of about 1100 ppmv, Heinze (2004) predicts a global decrease in $\mathrm{CaCO}_{3}$ production of approximately 38\%, slightly larger than the $27 \%$ simulated by Gehlen et al. (2007). This difference may be the result of the former study reaching this $p \mathrm{CO}_{2}$ level after 420 years compared with 140 years in the case of the latter one. The longer duration of the experiment allows for an amplification of ocean chemistry changes and contributes to the stronger decrease in calcification (see Chapter 14). Ridgwell et al. (2007) adjusted their parameterization to reproduce a dependency of $\mathrm{CaCO}_{3}$ production on $\Omega_{c}$ similar to Gehlen et al. (2007). The corresponding calcification feedback ranged from 6.5 to $7.7 \mathrm{Gt} \mathrm{C}$ at $3 \times p \mathrm{CO}_{2}$, compared with $5.6 \mathrm{Gt} \mathrm{C}$ at $4 \times$ $p \mathrm{CO}_{2}$ reported by Gehlen et al. (2007).

At first sight, one might thus conclude that the projected decrease in pelagic calcification and associated increase in atmospheric $\mathrm{CO}_{2}$ uptake by the ocean converge to modest levels of less than $10 \mathrm{Gt} C$ over the next century. However, these models rely largely on the same small experimental dataset for 
(A) Atmospheric $\mathrm{CO}_{2}$

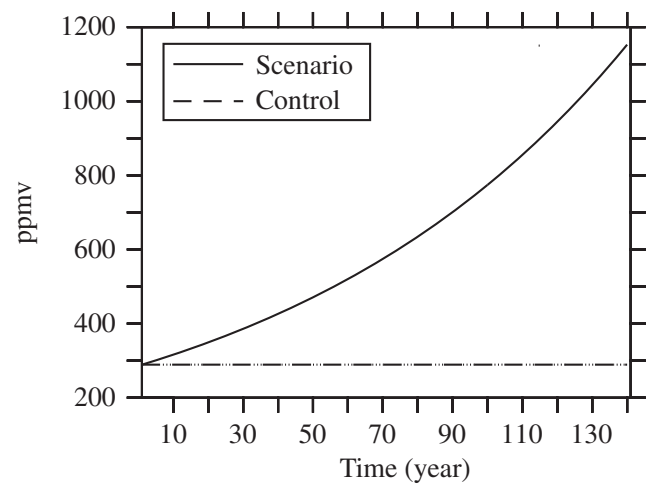

(C)

Net $\mathrm{CaCO}_{3}$ production and export

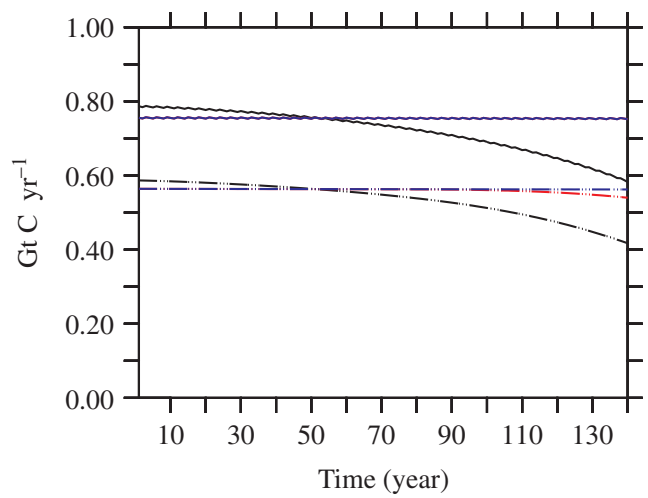

(E)

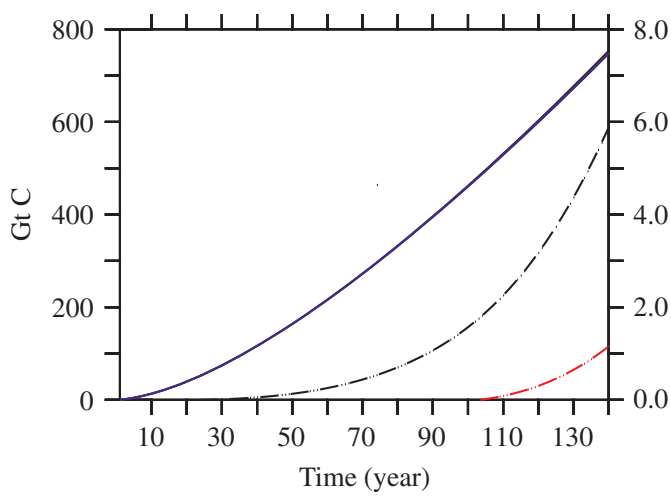

(B)

Calcite saturation state

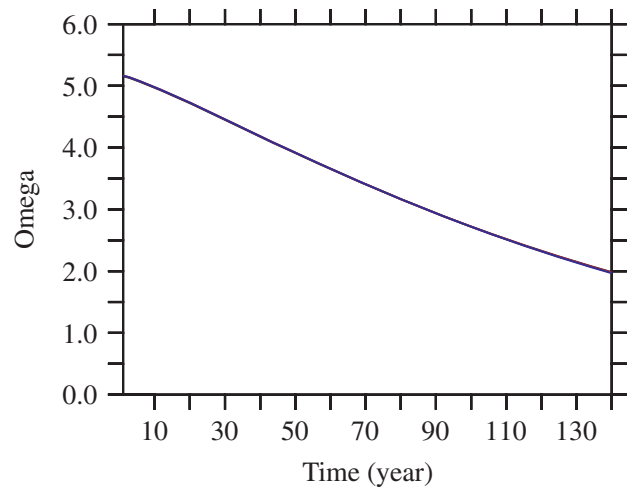

(D)

$\mathrm{CaCO}_{3}$ dissolution

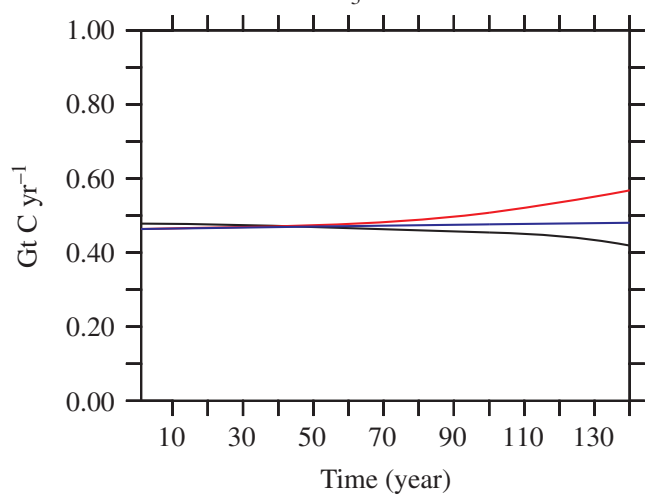

CAL01

CAL02

CAL03

Figure 12.2 (A) Atmospheric $\mathrm{CO}_{2}$ (ppmv) forcing used for the acidification scenarios and control runs. (B) Mean calcite saturation state of surface-ocean waters (0-100 m). (C) Global net $\mathrm{CaCO}_{3}$ production (full line) and export at $100 \mathrm{~m}$ (stippled line). (D) Global $\mathrm{CaCO}_{3}$ dissolution flux. (E) Cumulative air-sea flux of $\mathrm{CO}_{2}$ on the left axis, and carbon uptake in excess to CALO3 on the right axis. CAL01, production and dissolution of $\mathrm{CaCO}_{3}$ responds to changes in carbonate chemistry; CALO2, constant production, but dissolution responds to changes in carbonate chemistry; CALO3, constant production and dissolution (after Gehlen et al. 2007). 
deriving the functional relationship between seawater chemistry and $\mathrm{CaCO}_{3}$ production. Including a greater diversity of datasets results in a much larger spread of the calcification feedback estimates, ranging from 33 to $107 \mathrm{Gt} C$ at $1400 \mathrm{ppmv}$ for year 2300 (Ridgwell et al. 2007). New experimental data encompassing laboratory and mesocosm experiments, together with field observations, will allow us to derive process parameterizations that reflect a community response, rather than the upscaled sensitivity of a specific calcifying species (Ridgwell et al. 2009). Other effects, in particular warming and associated shifts in nutrient concentrations and irradiance, are likely to affect species distribution and primary production. It is not yet clear what impacts these concurrent changes will have on total pelagic calcification.

How will ocean acidification interact with climate change? Climate change translates into a net positive feedback on atmospheric $\mathrm{CO}_{2}$ (Friedlingstein et al. 2006). The negative calcification feedback will thus counteract the impact of climate change on rising atmospheric $\mathrm{CO}_{2}$ concentrations. In line with this consideration, Ridgwell et al. (2007) project an amplification of the calcification feedback by one-third in response to climate change by the year 3000 .

Marine $\mathrm{CaCO}_{3}$ production is a function of the biomass of calcifiers and their specific calcification rate. While ocean acidification will affect the latter, climate change is likely to drive major reorganizations of ecosystems, hence affecting the distribution and biomass of calcifying plankton. Isolating the direct effect of ocean chemistry on $\mathrm{CaCO}_{3}$ production in future projections of the marine $\mathrm{CaCO}_{3}$ cycle under climate change from the indirect effect of changes in POC production in response to temperature, irradiance, and nutrient availability is not straightforward. The point is well illustrated by Schmittner et al. (2008) who predict an approximate doubling of primary production and calcification by the year 4000 in response to global warming. While the discussion of future projections of primary and/or export production by coupled climate carbon cycle models is beyond the scope of this chapter, we note that some models converge in predicting their decrease (Steinacher et al. 2010). The picture gets even more complicated for models distinguishing different phytoplankton functional types (PFT). Here, the overall decrease in primary production and export production might go along with a shift in the relative proportion of primary production related to specific PFTs. For example, Bopp et al. (2005) report a replacement of diatoms by nanophytoplankton (the calcifying PFT in the model) in mid latitudes in response to the projected increase in stratification and diminished nutrient supply. From the preceding, it becomes evident that future studies across a variety of models should focus on the synergy between climate change and ocean acidification to try to disentangle the direct effects of chemistry from the effects of changes in temperature, irradiance and nutrient availability.

\subsubsection{The soft-tissue carbon pump}

The soft-tissue pump (Volk and Hoffert 1985) starts in the surface ocean with the production of organic carbon during photosynthesis, followed by the gravitational settling of particles across the water column, their remineralization, and the incorporation of the remaining fraction to surface sediments. The soft-tissue pump affects the surface-ocean carbonate system and thus air-sea exchange through the uptake of $C_{\mathrm{T}}$ together with a small increase in total alkalinity, leading to a decrease in surfaceocean $p \mathrm{CO}_{2}$ during photosynthesis. The $C_{\mathrm{T}}$ is replaced by $\mathrm{CO}_{2}$ released by the respiration of organic $\mathrm{C}$ within the mixed layer (zero net effect on air-sea exchange of $\mathrm{CO}_{2}$ ) or by mixing with deeper layers and is partly exchanged with the atmosphere. The time during which carbon bound into the particulate organic fraction is unavailable for exchange with the atmosphere is a function of remineralization depth and ranges from days for shallow remineralization in well-mixed waters to geological timescales for the fraction buried in marine sediments. A complete shutdown of the biological pump would yield an increase in atmospheric $\mathrm{CO}_{2}$ of between 150 and 220 ppmv (e.g. Gruber and Sarmiento 2002).

\subsubsection{Primary production}

Photosynthesis appears to benefit from increased levels of $\mathrm{CO}_{2}$ in some marine photosynthesizers (e.g. Rost et al. 2008). However, the extent of this 
$\mathrm{CO}_{2}$ fertilization depends on the physiological characteristics of individual phytoplankton groups, favouring in particular organisms with a comparable inefficient carbon acquisition pathway. Chapter 7 gives a detailed discussion of the effects of $\mathrm{CO}_{2}$ fertilization on phytoplankton. Enhanced photosynthesis per se will not cause a change in the net air-sea balance of $\mathrm{CO}_{2}$. This requires a net increase in net community production, i.e. the net balance between gross $\mathrm{CO}_{2}$ fixation and respiration, as it is net community production that provides the organic carbon that can be exported to depth. Furthermore, marine primary production is limited by irradiance and nutrients, and the total biomass is kept in check by grazing by zooplankton. Thus, only if those limiting factors can be overcome by $\mathrm{CO}_{2}$ fertilization, causing an additional export of organic carbon by the soft-tissue pump from the surface, will ocean acidification-induced changes in primary production cause earth system feedbacks.

\subsubsection{Export}

A powerful way for the soft-tissue pump to overcome the stringent control of nutrients on primary production and export is to alter the stoichiometric nutrient to carbon ratio of the organic matter produced and exported. Mesocosm experiments with natural plankton communities have indeed reported enhanced carbon drawdown under elevated $\mathrm{CO}_{2}$ (Riebesell et al. 2007). In these experiments, the stoichiometry of the carbon-to-nitrogen drawdown increased from 6.0 at $350 \mu$ atm to 8.0 at about 1050 ratm. While the significance of this excess carbon drawdown is not fully established yet and the mechanisms not fully understood, a possible route is via enhanced carbon fixation by the phytoplankton at higher $\mathrm{CO}_{2}$ levels, exudation of carbon-rich dissolved organic matter, and its subsequent export in form of aggregates (Arrigo 2007). To estimate the potential global impact of such a $\mathrm{CO}_{2}$-sensitive stoichiometry of C:N drawdown and, possibly, export, Oschlies et al. (2008) extrapolated the mesocosm results to the global ocean by means of a simple ecosystem-circulation model. They found that enhanced $\mathrm{C}: \mathrm{N}$ ratios could accomplish a negative feedback on atmospheric carbon levels for a business-as-usual scenario (SRES A2; see Chapter 15) amounting to $34 \mathrm{Gt} \mathrm{C}$ by the end of the century. This is of similar magnitude to the negative feedbacks estimated by modelling studies for $\mathrm{CO}_{2}$-sensitive calcification rates (Section 12.2.2.4). A dominant 'side' effect of the enhanced C: $\mathrm{N}$ ratios identified by Oschlies et al. (2008) is the enhanced oxygen consumption associated with the respiration of carbonrich organic matter at depth. In their model, this leads to a $50 \%$ expansion of oceanic suboxic regions, with direct consequences for the amount of nitrogen loss by denitrification and anaerobic ammonium oxidation (anammox), and hence for the oceanic inventory of fixed nitrogen.

The negative feedback of enhanced inorganic carbon-to-nitrogen consumption depends on the export of the additional organic carbon produced out of the surface mixed layer. For a pelagic Arctic ecosystem, Thingstad et al. (2008) showed that this depends on the presence or absence of growth-limiting nutrients for both autotrophic and heterotrophic processes. Depending on the nutrient status, enhanced production of organic carbon can even lead to reduced phytoplankton biomass as a result of stimulated bacterial competition for nutrients. Ecological impacts can also be induced by changes in temperature, which may result in shifts among autotrophic and heterotrophic processes (Wohlers et al. 2009). Future studies are needed to examine the combined effects of elevated $\mathrm{CO}_{2}$ and higher temperatures.

\subsubsection{Remineralization}

Most of the exported organic carbon is remineralized in the upper $1000 \mathrm{~m}$, but about $10 \%$ escapes to the deep ocean, where it is remineralized or buried in sediments and sequestered from the atmosphere on geological timescales. Therefore, changes in the efficiency with which the organic carbon is transported to depth provide a powerful means to alter the overall efficiency of the soft-tissue pump and thereby alter the air-sea balance of carbon, giving rise to an indirect group 1 type feedback.

The analysis of deep fluxes (water depth $>1000$ $\mathrm{m}$ ) of particulate inorganic and organic carbon suggests a close association of both phases (Armstrong et al. 2002; Klaas and Archer 2002). While the exact mechanism behind this observation awaits further elucidation (Passow and De La Rocha 2006), Armstrong et al. (2002) proposed that $\mathrm{CaCO}_{3}$ acts as 
the main carrier phase for POC to the deep ocean. Following their line of thought, $\mathrm{CaCO}_{3}$ would provide POC with excess density (ballasting) thereby increasing its sinking speed. It is also hypothesized that the association between $\mathrm{CaCO}_{3}$ and $\mathrm{POC}$ might protect the latter from bacterial degradation. If a control of POC fluxes by $\mathrm{CaCO}_{3}$ is assumed, then a decrease in $\mathrm{CaCO}_{3}$ production would imply less ballasting of POC fluxes, resulting in a decrease of its penetration depth. Particulate organic carbon would be remineralized at shallower depth and the overall efficiency of the biological pump would decrease resulting in a positive feedback to rising atmospheric $\mathrm{CO}_{2}$.

Barker et al. (2003) were the first to address the combined calcification and ballast feedback. Their box model sensitivity study confirms that the ballast effect counteracts the negative feedback of reduced calcification and, depending on the penetration depth of particle fluxes, might overcome it completely. In line with these results, Heinze (2004) reported a positive feedback attributed to a decrease in ballasting of POC fluxes which counteracts the small excess uptake of $\mathrm{CO}_{2}$ in response to a decrease in $\mathrm{CaCO}_{3}$ production. Taking into account climate change does not modify the picture. By the year 3000 , the combined effect of ballasting and reduced calcification yields a negative feedback to atmospheric $\mathrm{CO}_{2}$ of 50 ppmv compared to 125 ppmv for the calcification feedback only (Hofmann and Schellnhuber 2009). This study projects a strong decrease in meridional overturning circulation in response to climate change, leading to a decrease in ventilation of intermediate water masses. A decrease in penetration depth of POC due to the ballast effect and remineralization of POC at shallower depths will increase the oxygen demand. Physical and biogeochemical processes combine to draw $\mathrm{O}_{2}$ levels down and promote an extension of oxygen minimum zones. Oxygen minimum zones are sites of intense denitrification, a suboxic metabolic pathway yielding $\mathrm{N}_{2} \mathrm{O}$, a potent greenhouse gas. An increase of the ocean source of $\mathrm{N}_{2} \mathrm{O}$ would correspond to a positive feedback on the earth's radiative balance. This example illustrates the potential for cascading effects of ocean acidification running across multiple biogeochemical processes and cycles.

\subsection{The marine nitrogen cycle}

Ocean acidification affects the marine nitrogen cycle in a myriad of ways. On the one hand, this is a consequence of many biologically mediated transformations of nitrogen-involving $\mathrm{pH}$-dependent redox reactions (Fig. 12.3; Gruber 2008). On the other hand, many of these transformations are mediated by autotrophic organisms that require $\mathrm{CO}_{2}$ for their growth, so that these organisms may become stimulated by the higher availability of dissolved $\mathrm{CO}_{2}$ resulting from the uptake of anthropogenic $\mathrm{CO}_{2}$ from the atmosphere (e.g. Rost et al. 2008). Given the intricate and tight connection of the marine nitrogen cycle with those of carbon, phosphorus, oxygen, and many other important biogeochemical elements, any alteration of the marine nitrogen cycle will invariably impact upon the cycles of these other elements, possibly leading to feedbacks to the earth system. While we have just begun to quantitatively understand the impact of ocean acidification on certain isolated processes of the marine nitrogen cycle (e.g. the recent review by Hutchins et al. 2009), such as $\mathrm{N}_{2}$ fixation or nitrification, our knowledge of how these changes interact with each other and affect the other biogeochemical cycles is very poor. These interactions and their potential effects are addressed below, but the discussion and conclusions remain somewhat speculative.

\subsubsection{Nitrogen fixation}

Nitrogen fixation, the conversion of biologically unavailable $\mathrm{N}_{2}$ into organic forms of nitrogen, plays a central role in the marine nitrogen cycle, as it resupplies a substantial fraction of the nitrogen that is lost from the biologically available fixed nitrogen pool by denitrification. This process is undertaken by photoautotrophic organisms, of which the cyanobacterium Trichodesmium is the best known and studied (Capone et al. 1997). With the advent of molecular and genetic tools (Jenkins and Zehr 2008), the number of species known to be able to fix $\mathrm{N}_{2}$ is rapidly increasing (e.g. Zehr et al. 2001; Montoya et al. 2004), and the geographical areas where they have been reported to exist is expanding (Moisander et al. 2010).

Acidification experiments with Trichodesmium cultures have so far yielded a consistent positive 


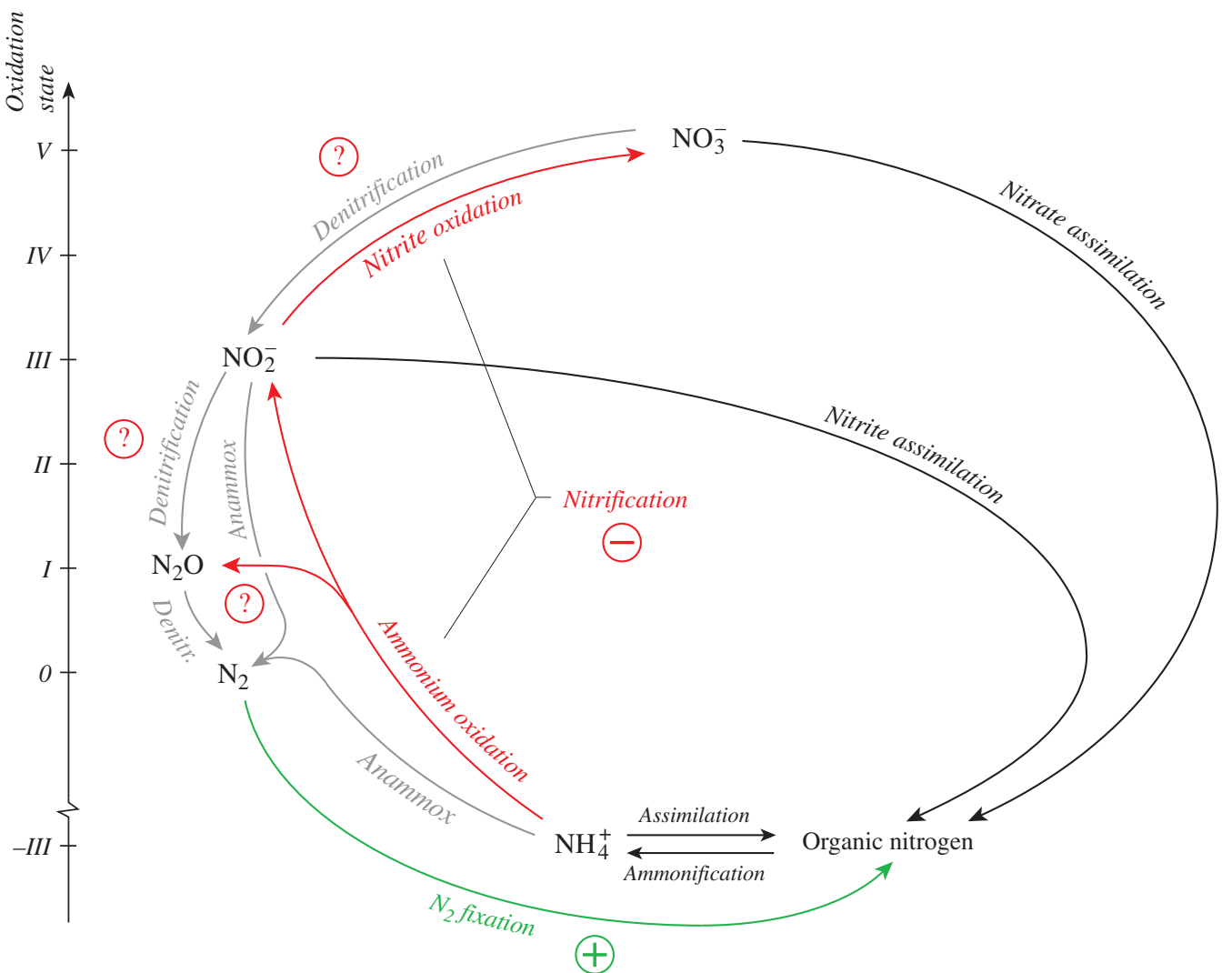

Figure 12.3 The marine nitrogen cycle highlighting the reactions that have been shown to be sensitive to changes in $\mathrm{pH}$ and the oceanic carbonate system. + and - indicate reactions stimulated or inhibited by ocean acidification. ?: effect of ocean acidification is unknown. anammox $=$ anaerobic ammonium oxidation. Adapted from Gruber (2008).

response of this organism to elevated $\mathrm{CO}_{2}$ and lowered pH (e.g. Barcelos e Ramos et al. 2007; Hutchins et al. 2007; Levitan et al. 2007; Kranz et al. 2009). As summarized by Hutchins et al. (2009), the mean enhancement of the rate of $\mathrm{N}_{2}$ fixation at elevated $\mathrm{CO}_{2}$ levels (750-1000 $\left.\mu \mathrm{atm}\right)$ from the six reported experiments with isolated cultures amounts to about $40 \pm 20 \%$. The only experiment with natural populations of Trichodesmium collected from the Gulf of Mexico also yielded increased fixation rates, although of smaller amplitude, i.e. between 6 and $41 \%$ (Hutchins et al. 2009). The enhanced rate of $\mathrm{N}_{2}$ fixation tends to be accompanied by enhanced rates of carbon fixation, so that the mean $\mathrm{C}: \mathrm{N}$ ratio of these organisms remained relatively constant (Barcelos e Ramos et al. 2007). This suggests that the primary mechanism responsible for the enhanced rate of $\mathrm{N}_{2}$ fixation is the $\mathrm{CO}_{2}$-induced increase in photosynthesis, providing additional energy for the fixation of $\mathrm{N}_{2}$.

Experiments with non-Trichodesmium $\mathrm{N}_{2}$ fixers are rare, in large part due to the fact that the majority of the identified species have not been cultured yet (Carpenter and Capone 2008). In the case of Crocosphaera watsonii, an enhancement was found that is very similar to that identified for Trichodesmium (Fu et al. 2008). In contrast, Nodularia spumigena exhibited almost no response to ocean acidification (Czerny et al. 2009). Thus, with the exception of one species, the majority of experiments point toward an enhancement of pelagic marine $\mathrm{N}_{2}$ fixation in response to ocean acidification. However, given the fact that the majority of the experiments were performed with the same 
strain of Trichodesmium, it is premature to draw firm conclusions. If it is nevertheless assumed that all nitrogen fixers are stimulated by ocean acidification, the global rate of marine $\mathrm{N}_{2}$ fixation may increase by more than $50 \mathrm{Tg} \mathrm{N} \mathrm{yr}^{-1}$ by 2100 . Relative to present-day rates of the order of $120 \pm 50 \mathrm{Tg}$ $\mathrm{N} \mathrm{yr}^{-1}$ (Gruber 2008), this represents a substantial acceleration of the rate of input of fixed nitrogen into the marine fixed nitrogen pool.

In nitrogen-limited regions of the ocean, such an addition has the potential to substantially increase marine productivity and thereby increase the export of organic carbon from the surface to the interior. This tends to enhance the uptake of $\mathrm{CO}_{2}$ from the atmosphere, i.e. this is a negative indirect group 2 type feedback (Table 12.1).

\subsubsection{Nitrification}

Nitrification, the combined processes of the oxidation of ammonium $\left(\mathrm{NH}_{4}^{+}\right)$to nitrite $\left(\mathrm{NO}_{2}^{-}\right)$, and the oxidation of nitrite to nitrate $\left(\mathrm{NO}_{3}^{-}\right)$is undertaken by two distinct classes of chemoautotrophic organisms which use the chemical energy released from these two processes as their source of energy: Nitrosomonas is responsible for the first oxidation step, i.e. the conversion from ammonium to nitrite, while Nitrobacter oxidizes nitrite to nitrate. Nitrification is inhibited by light, so it tends to be a dominant process only in the aphotic zone. However, a recent compilation by Yool et al. (2007) shows that a substantial amount of nitrification also occurs in the near-surface ocean.

Ocean acidification studies on marine nitrifiers are not as abundant as those that have been undertaken on marine $\mathrm{N}_{2}$ fixers, but tend to show a negative response, i.e. reduced rates at lower $\mathrm{pH}$ and elevated $\mathrm{CO}_{2}$ (Huesemann et al. 2002). This may be due to two effects (Hutchins et al. 2009). First, in the case of ammonium oxidation by Nitrosomonas, substrate limitation may be responsible. This is because these organisms prefer $\mathrm{NH}_{3}$, which becomes substantially less abundant relative to $\mathrm{NH}_{4}^{+}$in a more acidified ocean ( $\mathrm{pK}$ of $\mathrm{NH}_{3} / \mathrm{NH}_{4}^{+}$is around 9.2). Second, both Nitrosomonas and Nitrobacter may be responding directly to the increased concentration of dissolved $\mathrm{CO}_{2}$, which is their substrate for the synthesis of organic matter.
Fundamentally, as is the case for photoautotrophic organisms, one would expect a positive effect though, i.e. enhanced fixation of $\mathrm{CO}_{2}$ due to a higher efficiency of the $\mathrm{CO}_{2}$-fixing enzyme RubisCO (Rost et al. 2008).

Using results from the highly limited experiments, Hutchins et al. (2009) estimated a globalmean reduction of nitrification by about $10 \%$ for a business-as-usual scenario. This would result in a substantial shift of fixed nitrogen in the near-surface waters from the nitrate pool to the ammonium pool. However, the implications of this shift for earth system feedbacks are likely to be small because it does not directly alter the amount of fixed nitrogen in the ocean, keeping the impact on total production small. However, it is conceivable that this will cause alterations of the phytoplankton community structure, since not all phytoplankton can take up nitrate and ammonium equally well. For example, one could expect that species that are highly adapted to low nitrate and high ammonium concentrations, such as Prochlorococcus (Moore et al. 2002), would benefit at the expense of other phytoplankton that are more adapted to high nitrate and low ammonium concentrations (e.g. many diatoms).

A potentially larger effect may occur in shallow coastal sediments that are overlain by waters with relatively low nitrate concentrations. Here, the reduction of nitrate may cause a substrate-driven reduction in the rates of sedimentary denitrification (Blackford and Gilbert 2007). Given the fact that sedimentary denitrification is the largest sink for fixed nitrogen in the ocean (Gruber 2008), a reduction in this sink would increase the pool of fixed nitrogen in the ocean and hence probably increase biological productivity. However, there is little evidence that sedimentary denitrification is limited by nitrate on a global scale (Middelburg et al. 1996), so that this may remain a more local effect.

In summary, changes in nitrification induced by ocean acidification may lead to several indirect group 2 feedbacks. The direction of these feedbacks is unclear, but their magnitudes appear to be small. Given the limited extent of the studies undertaken so far, this conclusion remains tentative. 


\subsubsection{Denitrification}

Denitrification is a dissimilatory process that occurs only at extremely low to non-existent oxygen concentrations, but at appreciable levels of nitrate. Under such circumstances, heterotrophic microorganisms can use nitrate rather than dissolved oxygen as a terminal electron acceptor, i.e. they 'breathe' nitrate instead of oxygen. The threshold for the onset of this process occurs at oxygen concentrations of around 5 to $10 \mu \mathrm{mol} \mathrm{kg}{ }^{-1}$, or at the boundary between hypoxia and suboxia. In the present-day ocean, this condition is only met in the water column at a few locations, namely the eastern tropical North and South Pacific, the Arabian Sea, and a few more localized coastal regions. In contrast, many sediments underlying productive regions are completely void of oxygen (anoxic) at a depth of a few centimetres, making them sites of intense denitrification. Globally, denitrification is two times higher in the sediments than in the water column $\left(180 \pm 50 \mathrm{Tg} \mathrm{N} \mathrm{yr}^{-1}\right.$ vs $\left.65 \pm 20 \mathrm{Tg} \mathrm{N} \mathrm{yr}^{-1}\right)$, although there exists a considerable amount of debate about the exact magnitude of these processes (Gruber 2008).

Although so far unsupported by direct experiments, Hutchins et al. (2009) suggest that the heterotrophic microorganisms responsible for denitrification are not directly affected by ocean acidification. This is consistent with the fact that these organisms live and thrive in anoxic regions that naturally have a much lower $\mathrm{pH}$ than the rest of the ocean. However, ocean acidification-induced changes in the flux of organic matter that is entering such anoxic regions and changes in the extent and location of anoxic regions can lead to very substantial changes in marine denitrification, both in the water column and in the sediments. This may occur as a result of several mechanisms: first, a shallower remineralization of the organic matter sinking downward in response to reduced ballasting may lead to a higher oxygen demand in shallow waters at the expense of a smaller oxygen demand in deep waters (see Section 12.2.3.3). This may cause an expansion of anoxia, since it leads to the enhanced removal of oxygen in the upper thermocline where oxygen is already low in many locations (e.g. Keeling et al. 2010), while reducing the oxygen demand further down the water column, where oxygen concentration tends to be higher. A second mechanism is the increase of the C:N ratio induced by ocean acidification, which enhances the downward flux of organic carbon, thereby increasing the oxygen demand throughout the water column (see Section 12.2.3.2).

Hofmann and Schellnhuber (2009) simulated the impact of the first mechanism in a global model for a business-as-usual scenario, and found a $75 \%$ reduction in the export of $\mathrm{CaCO}_{3}$, a very substantial expansion of hypoxia (i.e. $\mathrm{O}_{2}$ concentrations below $60 \mu \mathrm{mol} \mathrm{kg}{ }^{-1}$ ), and a moderate increase of anoxic/ suboxic regions. Their model did not include denitrification, but the relatively small expansion of anoxic/suboxic waters would suggest that denitrification would not have increased substantially.

Oschlies et al. (2008) investigated the effect of changes in the $\mathrm{C}: \mathrm{N}$ ratio on marine oxygen in a global model using a business-as-usual scenario, and found a $50 \%$ increase in the ocean volume with suboxic conditions by the end of this century, which caused an increase in water-column denitrification of about $60 \mathrm{Tg} \mathrm{N} \mathrm{yr}^{-1}$. If sustained, such a loss of fixed nitrogen would lead to a decrease in the marine nitrogen inventory of the order of $10 \%$ in 1000 years, causing a corresponding decrease in marine productivity.

In conclusion, while denitrification is probably not directly affected by ocean acidification, it plays an important role in the sequence of processes that may ultimately cause substantial changes in the earth system.

\subsubsection{Nitrous oxide production}

Nitrous oxide $\left(\mathrm{N}_{2} \mathrm{O}\right)$ is produced in the ocean through at least two pathways (Fig.12.3; Gruber 2008). It is an intermediary product of denitrification, and under suboxic, but not completely anoxic, conditions its further reduction to $\mathrm{N}_{2}$ tends to proceed less efficiently. $\mathrm{N}_{2} \mathrm{O}$ is also produced during the oxidation of ammonium, and the fraction of the ammonium transformed into $\mathrm{N}_{2} \mathrm{O}$ instead of nitrite also tends to increase with lower oxygen concentrations. Most of the $\mathrm{N}_{2} \mathrm{O}$ produced in the ocean is emitted to the atmosphere, as only a small fraction is consumed in the anoxic regions of the ocean. 
While there is no experimental evidence that ocean acidification will affect $\mathrm{N}_{2} \mathrm{O}$ production directly, the decrease in oceanic oxygen induced by ocean acidification is bound to increase $\mathrm{N}_{2} \mathrm{O}$ production substantially. The reduced ballast effect could lead to higher rates of nitrification in low-oxygen regions which would substantially enhance $\mathrm{N}_{2} \mathrm{O}$ production associated with the nitrification pathway (Jin and Gruber 2003). The expansion of the anoxic regions caused by the altered C: $\mathrm{N}$ stoichiometry is likely to accelerate $\mathrm{N}_{2} \mathrm{O}$ production by the denitrification pathway. To date, no simulation has been undertaken to quantify this effect, but it is conceivable that oceanic $\mathrm{N}_{2} \mathrm{O}$ emissions could double in response to a doubling of the ocean's anoxic regions.

\subsubsection{Interactive effects - the future marine nitrogen cycle}

None of the above processes operate in isolation. Although the degree of coupling is intensively debated, nitrogen fixation and denitrification tend to be coupled (Deutsch et al. 2007; Gruber 2008). In addition, the marine oxygen content is likely to decrease substantially in response to global warming, irrespective of changes induced by ocean acidification. So what will be the response of the system as a whole? To date, no study has attempted to look at these nitrogen cycle-driven feedbacks holistically and in depth, so one can only provide a qualitative assessment. In addition, the answer is by nature speculative, since our understanding of how the different processes interact with each other is poor.

The marine nitrogen cycle will probably be accelerated in a high- $\mathrm{CO}_{2}$ ocean, with a substantially elevated rate of marine nitrogen fixation and a higher rate of (water-column) denitrification. This will decrease the mean residence time of fixed nitrogen in the ocean. Given the enhanced rates of sources and sinks, it is not possible to conclude anything about the potential generation of imbalances which are required to cause net changes in the oceanic fixed nitrogen inventory and changes in the biological pump that could alter the air-sea $\mathrm{CO}_{2}$ balance. It appears, however, that imbalances are not very likely and that ocean acidification-induced feedbacks to the earth system involving $\mathrm{N}_{2}$ fixation and denitrification will not become large at the global scale. On a regional level, and from the perspective of marine organisms that depend on sufficient oxygen levels to live, these changes will be relevant nevertheless-it is just that their impact on radiative forcing in the atmosphere will probably not be substantial. However, the level of confidence in this statement is very low. The story is different for $\mathrm{N}_{2} \mathrm{O}$ because evidence is mounting that ocean acidification will increase its production and emission into the atmosphere.

\subsection{The ocean as a source of atmospherically active trace gases}

In addition to being a source or a sink of some major greenhouse gases (e.g. $\mathrm{CO}_{2}$ and $\mathrm{N}_{2} \mathrm{O}$ ), the ocean is also a source of climatically active trace gases to the marine atmosphere (see Chapter 11 for detailed information). Among them, dimethyl sulphide (DMS) is a gaseous sulphur compound produced by marine biota in surface seawater. Once emitted to the atmosphere, it undergoes rapid oxidation to produce particles that can modify the optical properties of clouds, thereby influencing climate. Iodoand bromocarbon gases are also produced in surface seawater and can be outgassed to the atmosphere. They represent a major source of halogens to the marine atmosphere where their oxidation can produce reactive radicals. These radicals play a role in the photochemical loss of tropospheric ozone (a major greenhouse gas), but also in the regulation of stratospheric ozone. In addition, they can contribute to particle formation and modify the optical properties of clouds, thereby affecting climate.

For more than 20 years now, it has been proposed that marine emissions of DMS are sensitive to climatic change and that the radiative budget of the earth is in turn sensitive to modifications of the marine DMS source (Charlson et al. 1987). Climate model simulations suggested that a $50 \%$ decrease in DMS emissions could result in a net increase in the mean surface temperature of $1.6^{\circ} \mathrm{C}$ (Gunson et al. 2006). Changes in the production and in the sea-toair flux of DMS resulting from ocean acidification could thus have a significant impact on climate and hence form an indirect group 1 type feedback. A detailed presentation of the chemistry of DMS and 
the role of marine biota in controlling its cycle is given in Chapter 11. Impacts of ocean acidification on DMS emissions and implications for climate feedbacks are still largely unknown. Published studies report contrasting results. Potential effects have so far not been included in coupled climatemarine biogeochemistry models.

\subsection{Conclusion and perspectives}

This chapter has addressed biogeochemical impacts for which experimental evidence is available and which, with the exception of atmospheric trace gases, have been addressed in model studies. As a result, we have largely focused on the $\mathrm{C}$ and $\mathrm{N}$ cycles. It is likely that other major cycles also will be affected by ocean acidification either directly (Fe; Shi et al. 2010; Breitbarth et al. 2010) or indirectly through changes in elemental ratios of export production (P and Si; Hutchins et al. 2009 and references therein). At present, however, experimental evidence is too sparse, and often contradictory, to allow inferences of biogeochemical consequences across the whole spectrum of elements.

Not surprisingly, early research efforts on the impacts of ocean acidification focused on marine calcification. Because of its seemingly straightforward incorporation into biogeochemical models and the negative feedback to atmospheric $\mathrm{CO}_{2}$ levels associated with its decrease, this particular impact was rapidly implemented in global ocean biogeochemical models. Ocean acidification research is a field of rapidly expanding knowledge, and recent evidence suggests that the response of marine calcifiers to changes in carbonate chemistry is more complex than originally expected. Within-species and between-species variability, as well as processes such as acclimatization and adaptation, challenge the approaches currently used in biogeochemical modelling. These mostly rely on the representation of a limited number of plankton groups, to which major biogeochemical functions are assigned, e.g. $\mathrm{CaCO}_{3}$ production, biogenic silica formation and $\mathrm{N}_{2}$ fixation. If environmental conditions (irradiance, temperature, nutrients) cross a critical threshold for a given plankton functional type, it disappears from the model world. There is no shift between species within a given plankton functional type, nor potential for acclimation and adaptation. The increase in functional types in an effort to better capture ecosystem complexity is limited by the lack of available data to constrain model parameterizations. The evaluation of the impacts of ocean acidification and climate change might well require the development of a new generation of ecosystem models (Follows et al. 2007; Barton et al. 2010) or optimality-based adaptive models (Bruggeman and Kooijman 2007; Pahlow et al. 2008).

Elemental cycles are tightly coupled through reactions involved in organic matter synthesis and remineralization. One has just begun to evaluate how changes in one cycle spread to another as exemplified by studies linking changes in the export efficiency of the biological pump either mediated by $\mathrm{CaCO}_{3}$ production (Hofmann and Schellnhuber 2009) or export stoichiometry (Oschlies et al. 2008) to ocean oxygen inventory and the nitrogen cycle. Clearly, the study of biogeochemical impacts of ocean acidification, its interaction with climate change, and feedbacks to the earth system are at an early stage.

\subsection{Acknowledgements}

We acknowledge financial support from grant GOCE-511176 (EU FP6 RTP project CARBOOCEAN) and grant 211384 (EU FP7 RTP project EPOCA) provided by the European Commission.

\section{References}

Archer, D. (2005). Fate of fossil fuel $\mathrm{CO}_{2}$ in geologic time. Journal of Geophysical Research, 110, C09S05, doi:10.1029/2004JC002625.

Archer, D. and Maier-Reimer, E. (1994). Effect of deep-sea sedimentary calcite preservation on atmospheric $\mathrm{CO}_{2}$ concentration. Nature, 367, 260-3.

Arrigo, K. (2007). Carbon cycle: marine manipulations. Nature, 450, 491-2.

Armstrong, R.A., Lee, C., Hedges, J.I., Honjo, S., and Wakeham, S.G. (2002). A new, mechanistic model for organic carbon fluxes in the ocean based on the quantitative association of POC with ballast minerals. DeepSea Research II, 49, 219-36.

Barcelos e Ramos, J., Biswas, H., Schulz, K.G., LaRoche, J., and Riebesell, U. (2007). Effect of rising atmospheric 
carbon dioxide on the marine nitrogen fixer Trichodesmium. Global Biogeochemical Cycles, 21, GB2028, doi:10.1029/2006GB002898.

Barker, S., Higgins, J.A., and Elderfield, H. (2003). The future of the carbon cycle: review, calcification response, ballast and feedback on atmospheric $\mathrm{CO}_{2}$. Philosophical Transactions of the Royal Society A: Mathematical, Physical and Engineering Sciences, 361, 1977-1998.

Barton, A.D., Dutkiewicz, S., Flierl, G., Bragg, J., and Follows, M.J. (2010). Patterns of diversity in marine phytoplankton. Science, 327, 1509-11.

Blackford, J.C. and Gilbert, F.J. (2007). pH variability and $\mathrm{CO}_{2}$ induced acidification in the North Sea. Journal of Marine Systems, 64, 229-41.

Bopp, L., Aumont, O., Cadule, P., Alvain, S., and Gehlen, M. (2005). Response of diatoms distribution to global warming and potential implications: a global model study. Geophysical Research Letters, 32, L19606, doi:10.1029/2005GL023653.

Breitbarth, E., Bellerby, R.J., Neill, C.C. et al. (2010). Ocean acidification affects iron speciation during a coastal seawater mesocosm experiment. Biogeosciences, 7, 1065-73.

Brewer, P.G. and Peltzer, E.T. (2009). Limits to marine life. Science, 324, 347-8.

Bruggeman, J. and Kooijman, S.A.L.M. (2007). A biodiversity-inspired approach to aquatic ecosystem modeling. Limnology and Oceanography, 52, 1533-44.

Caldeira, K. and Wickett, M.E. (2003). Anthropogenic carbon and ocean $\mathrm{pH}$. Nature, 425, 365.

Capone, D.G., Zehr, J.P., Paerl, H.W., Bergman, B., and Carpenter, E.J. (1997). Trichodesmium, a globally significant marine cyanobacterium. Science, 276, 1221-9.

Carpenter, E.J. and Capone, D.G. (2008). Nitrogen fixation in the marine environment. In: D.G. Capone, D.A. Bronk, M.R. Mulholland, and E.J. Carpenter (eds), Nitrogen in the marine environment, pp. 141-98. Elsevier, Amsterdam.

Charlson, R.J., Lovelock, J.E., Andreae, M.O., and Warren, S.G. (1987). Oceanic phytoplankton, atmospheric sulfur, cloud albedo and climate. Nature, 326, 655-61.

Czerny, J., Barcelos e Ramos, J., and Riebesell, U. (2009). Influence of elevated $\mathrm{CO}_{2}$ concentrations on cell division and nitrogen fixation rates in the bloomforming cyanobacterium Nodularia spumigena. Biogeosciences, 6, 1865-75.

Deutsch, C., Sarmiento, J.L., Sigman, D.M., Gruber, N., and Dunne, J.P. (2007). Spatial coupling of nitrogen inputs and losses in the ocean, Nature, 445, 163-7.

Fabry, V.J., Seibel, B.A., Feely, R.A., and Orr, J.C. (2008). Impacts of ocean acidification on marine fauna and ecosystem processes. ICES Journal of Marine Sciences, 65, $414-32$.
Falkowski, P., Scholes, R.J., Boyle, E. et al. (2000). The global carbon cycle: a test of our knowledge of Earth as a system. Science, 290, 291-6.

Follows, M.J., Dutkiewicz, S., Grant, S., and Chisholm, S.W. (2007). Emergent biogeography of microbial communities in a model ocean. Science, 315, 1843-6.

Friedlingstein P., Cox, P., Betts, R. et al. (2006). Climatecarbon cycle feedback analysis: results from the C4MIP model intercomparison. Journal of Climate, 19, 3337-53.

Fu, F-X., Mulholland, M.R., Garcia, N.S. et al. (2008). Interactions between changing $p \mathrm{CO}_{2}, \mathrm{~N}_{2}$ fixation, and $\mathrm{Fe}$ limitation in the marine unicellular cyanobacterium Crocosphaera. Limnology and Oceanography, 53, 2472-2484.

Gangstø, R., Gehlen, M., Schneider, B., Bopp, L., Aumont, O., and Joos, F. (2008). Modeling the marine aragonite cycle: changes under rising carbon dioxide and its role in shallow water $\mathrm{CaCO}_{3}$ dissolution. Biogeosciences, 5, 1057-72.

Gangstø R. Joos, F. and Gehlen, M. (2011). Sensitivity of pelagic calcification to ocean acidification, Biogeosciences, 8, 433-58.

Gehlen, M., Bassinot, F., Chou, L., and McCorkle, D. (2005). Reassessing the dissolution of marine carbonates: II. Reaction kinetics. Deep-Sea Research I, 52, 1461-76.

Gehlen, M., Gangstø, R., Schneider, B., Bopp, L., Aumont, O., and Ethé, C. (2007). The fate of pelagic $\mathrm{CaCO}_{3}$ production in a high $\mathrm{CO}_{2}$ ocean: a model study. Biogeosciences, 4, 505-19.

Gruber, N. (2008). The marine nitrogen cycle: overview and challenges. In: D.G. Capone, D.A. Bronk, M.R. Mulholland, and E.J. Carpenter (eds), Nitrogen in the marine environment, pp. 1-50. Elsevier, Amsterdam.

Gruber, N. and Sarmiento, J.L. (2002). Large-scale biogeochemical/physical interactions in elemental cycles. In: A.R. Robinson, J.J. McCarthy, and B.J. Rothschild (eds), The sea: biological-physical interactions in the oceans, pp. 337-99. John Wiley and Sons, Inc., New York.

Gunson, J.R., Spall, S.A., Anderson, T.R., Jones, A., Totterdell, I.J., and Woodage, M.J. (2006). Climate sensitivity to ocean dimethylsulphide emissions. Geophysical Research Letters, 33, L07701, doi:10.1029/2005GL024982.

Hales, B. and Emerson, S. (1997). Evidence in support of first order dissolution kinetics of calcite in seawater. Earth and Planetary Science Letters, 148, 317-27.

Heinze, C. (2004). Simulating oceanic $\mathrm{CaCO}_{3}$ export production in the greenhouse. Geophysical Research Letters, 31, L16308, doi:10,1029/2004GL020613.

Hofmann, M. and Schellnhuber, H.-J. (2009). Oceanic acidification affects marine carbon pump and triggers extended marine oxygen holes. Proceedings of the National Academy of Sciences USA, 106, 3017-22. 
Huesemann, M.H., Skillman, A.D., and Crecelius, E.A. (2002). The inhibition of marine nitrification by ocean disposal of carbon dioxide. Marine Pollution Bulletin, 44, 142-8.

Hutchins, D.A., Fu, F.-X., Zhang, Y. et al. (2007). $\mathrm{CO}_{2}$ control of Trichodesmium $\mathrm{N}_{2}$ fixation, photosynthesis, growth rates and elemental ratios: implications for past, present and future ocean biogeochemistry. Limnology and Oceanography, 52, 1293-304.

Hutchins, D.A., Mulholland, M.R., and Fu, F. (2009). Nutrient cycles and marine microbes in a $\mathrm{CO}_{2}$-enriched ocean. Oceanography, 22, 128-45.

Iglesias-Rodriguez, M.D., Halloran, P.R., Rickaby, R.E.M. et al. (2008). Phytoplankton calcification in a high- $\mathrm{CO}_{2}$ world. Science, 320, 336-40.

Jenkins, B.D. and Zehr, J.P. (2008). Molecular approaches to the nitrogen cycle. In: D.G. Capone, D.A. Bronk, M.R. Mulholland, and E.J. Carpenter (eds), Nitrogen in the marine environment, pp. 1303-44. Elsevier, Amsterdam.

Jin, X. and Gruber, N. (2003). Offsetting the radiative benefit of ocean iron fertilization by enhancing $\mathrm{N}_{2} \mathrm{O}$ emissions. Geophysical Research Letters, 30, 2249, doi: 10.1029/2003GL018458.

Jin, X., Gruber, N., Frenzel, H., Doney, S.C., and McWilliams, J.C. (2008). The impact on atmospheric $\mathrm{CO}_{2}$ of iron fertilization induced changes in the ocean's biological pump. Biogeosciences, 5, 385-406.

Keeling, R.F., Körtzinger, A., and Gruber, N. (2010). Ocean deoxygenation in a warming world. Annual Review of Marine Science, 2, 199-229.

Keir, R.S. (1980). The dissolution kinetics of biogenic carbonate in seawater. Geochimica et Cosmochimica Acta, 44, 241-52.

Khatiwala, S., Primeau, F., and Hall, T. (2009). Reconstruction of the history of anthropogenic $\mathrm{CO}_{2}$ concentrations in the ocean. Nature, 462, 346-9.

Klaas, C. and Archer, D.E. (2002). Association of sinking organic matter with various types of mineral ballast in the deep sea: implications for the rain ratio. Global Biogeochemical Cycles, 16, 1116, doi:10.1029/2001GB001765.

Kranz, S.A., Sültemeyer, D., Richter, K.-U., and Rost, B. (2009). Carbon acquisition by Trichodesmium: the effect of $\mathrm{COO}_{2}$ and diurnal changes. Limnology and Oceanography, 54, 548-59.

Levitan, O., Rosenberg, G., Setlik, I. et al. (2007). Elevated $\mathrm{CO}_{2}$ enhances nitrogen fixation and growth in the marine cyanobacterium Trichodesmium. Global Change Biology, 13, 531-8.

Middelburg, J.J., Soetaert, K., Herman, P.M.J., and Heip, C.H.R. (1996). Denitrification in marine sediments: a model study. Global Biogeochemical Cycles, 10, 661-73.

Moisander, P.H., Beinart, R.A., Hewson, I. et al. (2010). Unicellular cyanobacterial distributions broaden the oceanic $\mathrm{N}_{2}$ fixation domain. Science, 327, 1512-14.
Montoya, J.P., Holl, C.M., Zehr, J.P., Hansen, A., Villareal, T.A., and Capone, D.G. (2004). High rates of $\mathrm{N}_{2}$-fixation by unicellular diazotrophs in the oligotrophic Pacific. Nature, 430, 1027-32.

Morse, J.W., Arvidson, R.S., and Lüttge, A. (2007). Calcium carbonate formation and dissolution. Chemical Reviews, 107, 342-81.

Moore, L.R., Post, A.F., Rocap, G., and Chisholm, S.W. (2002). Utilization of different nitrogen sources by the marine cyanobacteria Prochlorococcus and Synechococcus. Limnology and Oceanography, 47, 989-96.

Oschlies, A. (2009). Impact of atmospheric and terrestrial $\mathrm{CO}_{2}$ feedbacks on fertilization-induced marine carbon uptake. Biogeosciences, 6, 1603-13.

Oschlies, A., Schulz, K.G., Riebesell, U., and Schmittner, A. (2008). Simulated 21st century's increase in oceanic suboxia by $\mathrm{CO}_{2}$ enhanced biotic carbon export. Global Biogeochemical Cycles, 22, GB4008, doi: 10.1029/2007GB003147.

Pahlow, M., Vezina, A.F., Casault, B. et al. (2008). Adaptive model of plankton dynamics for the North Atlantic. Progress in Oceanography, 76, 151-91.

Passow, U. and De La Rocha, C.L. (2006). Accumulation of mineral ballast on organic aggregates. Global Biogeochemical Cycles, 20, GB1013, doi:10.1029/2005GB002579.

Ridgwell, A. and Hargreaves, J.C. (2007). Regulation of atmospheric $\mathrm{CO}_{2}$ by deep-sea sediments in an Earth System Model. Global Biogeochemical Cycles, 21, GB2008, doi: 10.1029/2006GB002764.

Ridgwell, A., Zondervan, I., Hargreaves, J.C., Bijma, J., and Lenton, T.M. (2007). Assessing the potential longterm increase of oceanic fossil fuel $\mathrm{CO}_{2}$ uptake due to $\mathrm{CO}_{2}$-calcification feedback. Biogeosciences, 4, 481-92.

Ridgwell, A., Schmidt, D.N., Turley, C. et al. (2009). From laboratory manipulations to Earth system models: scaling calcification impacts of ocean acidification. Biogeosciences, 6, 2611-23.

Riebesell, U., Schulz, K.G., Bellerby, R.G.J. et al. (2007). Enhanced biological carbon consumption in a high $\mathrm{CO}_{2}$ ocean. Nature, 450, 545-8.

Rost, B., Zondervan, I., and Wolf-Gladrow, D. (2008). Sensitivity of phytoplankton to future changes in ocean carbonate chemistry: current knowledge, contradictions and research directions. Marine Ecology Progress Series, 373, 227-37.

Sarmiento, J.L., Le Quéré, C., and Pacala, S.W. (1995). Limiting future atmospheric carbon dioxide. Global Biogeochemical Cycles, 9, 121-37.

Sarmiento, J.L., Hughes, T.M.C., Stouffer, R.J., and Manabe, S. (1998). Simulated response of the ocean carbon cycle to anthropogenic climate warming. Nature, $393,245-9$. 
Schmittner, A., Oschlies, A., Matthews, H.D., and Galbraith, E.D. (2008). Future changes in climate, ocean circulation, ecosystems, and biogeochemical cycling simulated for a business-as-usual $\mathrm{CO}_{2}$ emission scenario until year 4000 AD. Global Biogeochemical Cycles, 22, GB1013, doi: 10.1029/2007GB002953.

Shi, D., Xu, Y., Hopkinson, B.M., and Morel, F.M.M. (2010). Effect of ocean acidification on iron availability to marine phytoplankton. Science, 327, 676-9.

Steinacher, M., Joos, F., Frölicher, T.L. et al. (2010). Projected 21st century decrease in marine productivity: a multimodel analysis. Biogeosciences, 7, 979-1005.

Sundquist, E.T. (1990). Influence of deep-sea benthic processes on atmospheric $\mathrm{CO}_{2}$. Philosophical Transactions of the Royal Society A: Mathematical, Physical and Engineering Sciences, 331, 155-65.

Thingstad, T.F., Bellerby, R.G.J., Bratbak, G. et al. (2008). Counterintuitive carbon-to-nutrient coupling in an Arctic pelagic ecosystem. Nature, 455, 387-90.
Volk, T. and Hoffert, M.I. (1985). Ocean carbon pumps: analysis of relative strengths and efficiencies in oceandriven atmospheric $\mathrm{CO}_{2}$ changes. In: E.T. Sundquist and W.S. Broecker (eds), The carbon cycle and atmospheric $\mathrm{CO}_{2}$ : natural variations archean to present, pp. 99-110. American Geophysical Union, Washington, DC.

Wohlers, J., Engel, A., Zöllner, E. et al. (2009). Changes in biogenic carbon flow in response to sea surface warming. Proceedings of the National Academy of Sciences USA, 106, 7067-72.

Yool, A., Martin, A.P., Fernández, C., and Clark, D.R. (2007). The significance of nitrification for oceanic new production. Nature, 447, 999-1002.

Zehr, J.P., Waterbury, J.B., Turner, P.J. et al. (2001). Unicellular cyanobacteria fix $\mathrm{N}_{2}$ in the subtropical North Pacific Ocean. Nature, 412, 635-8.

Zondervan, I., Zeebe, R.E., Rost, B., and Riebesell, U. (2001). Decreasing marine biogenic calcification: a negative feedback on rising atmospheric $\mathrm{pCO}_{2}$. Global Biogeochemical Cycles, 15, 507-16. 